\title{
Effects of Soil Exogenous Nitrogen on Bamboo Shoots, Photosynthetic Characteristics, and Nitrogen Metabolism in Dendrocalamus Latiflorus Munro
}

Fan Lili ( 2180428002@fafu.edu.cn )

Fujian Agriculture and Forestry University https://orcid.org/0000-0001-9673-0881

Lili Fan

Fujian Agriculture and Forestry University

Muhammad Waqqas Khan Tarin

Fujian Agriculture and Forestry University

Yongzhen Han

Fujian Agriculture and Forestry University

Wenfeng Hu

Fujian Agriculture and Forestry University

Jundong Rong

Fujian Agriculture and Forestry University

Tianyou He

Fujian Agriculture and Forestry University

Yushan Zheng

Fujian Agriculture and Forestry University

\section{Original Article}

Keywords: nitrogen application, bamboo seedlings, photosynthetic physiological characteristics, nitrogenrelated enzyme activity

Posted Date: November 29th, 2021

DOI: https://doi.org/10.21203/rs.3.rs-1070177/v1

License: (9) (1) This work is licensed under a Creative Commons Attribution 4.0 International License. Read Full License 


\section{Abstract}

\section{Background}

Nitrogen $(\mathrm{N})$ is an essential nutrient element that is involved in almost every aspect of a plant's physiological mechanism. Therefore, the current research aims to determine the optimal amount of $\mathrm{N}$ fertilizer to bamboo seedlings for better nutrient management practices to minimize $\mathrm{N}$ pollution in bamboo forests. We evaluated the physiological response of Dendrocalamus latiflorus Munro grown under five varying levels of $\mathrm{N}$ fertilizer; such as N0, N1, N2, N3, N4, and N5 $(0,1.5,3.0,4.5,6.0$, and 7.5 $g \cdot$ pot $^{-1}$, respectively).

Results

$\mathrm{N} 4$ treatment had a significant effect on the number of shoots, which was greatly correlated with net photosynthetic rate $\left(P_{\mathrm{n}}\right)$ and photosynthetic pigment (Car, Chls, and $\mathrm{Chl} \mathrm{a} / \mathrm{b}$ ) as well as N-related indices [leaf $\mathrm{N}$, leaf ammonium $\mathrm{N}\left(\mathrm{NH}_{4}{ }^{+}-\mathrm{N}\right)$, and nitrate reductase (NR)]. $\mathrm{N}$ supply significantly increased soil carbon and $\mathrm{N}$ contents, which could be conducive to the accumulation of leaf chlorophyll content, improving leaf photosynthesis mechanism, and accelerating $\mathrm{N}$ metabolism and conversion through an enzymatic reaction.

\section{Conclusions}

Overall, the $\mathrm{N}$ application of $6 \mathrm{~g} \cdot \mathrm{pot}^{-1}$ was advantageous to improve physiological characteristics and shoot production of seedlings. As a consequence, we suggest that optimal nitrogen supply can be effective to improve soil fertility to attain high bamboo production.

\section{Background}

Nitrogen $(\mathrm{N})$ is an essential macronutrient element that is required by plants in higher amounts relative to other essential nutrients (Kirova et al. 2005). $\mathrm{N}$ is involved in almost every aspect of a plant's physiological metabolism being a most essential nutritional component (Kishorekumar et al. 2020a). At the physiological level, $\mathrm{N}$ may trigger both the $\mathrm{NO}_{3}$ assimilatory mechanism and the regulation of carbon (C) metabolism that can provide C skeletons and reductants for this process (Stitt 1999). At the developmental stage, $\mathrm{N}$ regulates activities such as leaf expansion (Walch-Liu et al. 2000), root branching (Forde \& Lorenzo 2002), and resource allocation between shoot and root growth (Scheible et al. 1997). $\mathrm{N}$ and other elements in the plant are responsible for the synthesis of amino acids, proteins, nucleic acids, chlorophyll, and other compounds (Talukder et al. 2016, Wen et al. 2020). Furthermore, N can also regulate the adaptation mechanism of plants to the environment and play an important role in the adaptation of plants to adversity (Krouk et al. 2010). Simultaneously, exogenous $\mathrm{N}$ can significantly affect the $\mathrm{N}$ metabolism in plants as well as a certain degree of impact on its related enzymatic activities, thereby affecting plant growth (Xing et al. 2018). 
$\mathrm{N}$, being a necessary component, has the potential to change plant proteins as well as plant photosynthesis (Kishorekumar et al. 2020b, Liu et al. 2020). In general, when the $\mathrm{N}$ concentration increases, the leaf's photosynthetic rate $\left(P_{\mathrm{n}}\right)$ and transpiration rate $\left(T_{\mathrm{r}}\right)$ increases while the intercellular $\mathrm{CO}_{2}$ concentration $\left(C_{\mathrm{i}}\right)$ decreases ( $\mathrm{Li}$ et al. 2017, Mu \& Chen 2021). Furthermore, increasing the quantity of $\mathrm{N}$ fertilizer used may enhance the chlorophyll content of leaves and. In addition, increasing the amount of $\mathrm{N}$ fertilizer can also increase the leaf's chlorophyll contents and alleviate the reduction in photosynthetic efficiency (Zhou et al. 2017a). Previous studies have shown that $\mathrm{N}$ fertilizer application can effectively increase the chlorophyll contents and net photosynthetic rate of agricultural or horticultural crops, such as rice (Kurai et al. 2011, Zhou et al. 2017b), wheat (Kataria \& Guruprasad 2015), peanut (Liu et al. 2019b), etc. As a result, in the current research, we attempt to gain insight into the photosynthetic capacity of Dendrocalamus latiflorus Munro grown under varying $\mathrm{N}$ levels.

Soil is a part of the ecosystem, where the contents of essential nutrients can not only reveal the utilization of soil nutrients but also explore the regulatory and metabolic balance mechanisms of elements such as $\mathrm{C}$ and $\mathrm{N}$ in plants and soil (Kleinhenz et al. 2003). Since, both the $\mathrm{C}$ and $\mathrm{N}$ are essential nutrient elements in the soil and are required for plant growth and development (Krapp \& Castaings 2012). Plants uptake the nutrients from the soil via roots, which are greatly influenced by the external environment, especially by fertilizers (Bargaz et al. 2018). Therefore, the nutritional changes ( $\mathrm{C}$ and $\mathrm{N}$ ) in plants can explore the nutrient distribution ratio and status of plants, as well as the internal connection between soil and plants.

$\mathrm{N}$ metabolism is one of the important physiological metabolic processes in plants (O'Brien et al. 2016). Nitrate reductase (NR) is the main $\mathrm{N}$ metabolizing enzyme of higher plants. The metabolic enzyme activity of plant leaves and roots is related to the accumulation of $\mathrm{N}$ in plants (Fu et al. 2020b). Glutamine synthetase (GS) is the first enzyme to be isolated, purified, and identified from plants, and it is also the first enzyme to be found to be related to the storage form of plant N (Seabra \& Carvalho 2015). GS converts the inorganic ammonia absorbed by plants into an organic form in glutamine (GIn) and glutamic acid (Glu) as $\mathrm{N}$ donors in the biosynthesis of $\mathrm{N}$-containing organics in higher plants (Yang et al. 2016). NR and GS are all inducible enzymes that affect the metabolism and transformation of $\mathrm{N}$ in plants, which play an important role in the absorption and transformation of nutrient elements to affect plant growth.

Fertilization is an important measure to improve bamboo cultivation. As one of the main factors affecting bamboo growth, $\mathrm{N}$ has a great influence on the growth and development of bamboo. Previous research showed that optimum $\mathrm{N}$ fertilization can effectively improve photosynthetic capacity, growth, and productivity of shoots and timber in bamboo forests (Xu et al. 2014, Gao et al. 2016). At present, N fertilization in bamboo forests is relatively systematic in China, but the phenomenon of soil deterioration and environmental degradation caused by fertilization still exists (Zhu \& Chen 2002). Increased use of $N$ fertilizers will also exacerbate the increase in nitrous oxide (N2O) emissions from the soil (Xu et al. 2014). In order to increase the yield of bamboo forests and protect the ecological environment, it is necessary to further improve the utilization efficiency of $\mathrm{N}$ fertilizer in bamboo forests. 
D. latiflorus Munro has become the main cultivated bamboo species for shoots in China by the features of its strong adaptability, long shoot period, and high yield of bamboo shoots. D. latiflorus Munro has a large leaf area and continuous rainfall in the early stage of bamboo shoots in southern China, which would exacerbate the lack of sunlight in the forest understory. Nutrient management can also alleviate the stress caused by low light, improve the photosynthetic capacity of bamboo, and increase its productivity. Therefore, in the current study, $D$. latiflorus Munro seedlings were established under various levels of N-based fertilizer, to assess its efficacy on shoot growth. The study will provide valuable insights into optimum $\mathrm{N}$ requirements for the growth of $D$. latiflorus Munro. The main goals of our experiment were (i) to distinguish the effect of different levels of $\mathrm{N}$ on physiological and biochemical attributes of $D$. latiflorus Munro; (ii) to identify the effect of $\mathrm{N}$ application on soil properties and the growth pattern in $D$. latiflorus Munro; (iii) to determine the reasonable amount of $\mathrm{N}$ applied to bamboo shoots.

\section{Materials And Methods}

\section{Study sites}

The greenhouse experiment was carried out in College of Forestry, Fujian Agriculture and Forestry. The study site is located $\left(119^{\circ} 13^{\prime} 51.18^{\prime \prime} \mathrm{E}, 2^{\circ} 05^{\prime} 4.35^{\prime \prime} \mathrm{N}\right)$ in Fuzhou, Fujian province, China (Figure. 1). The site has a subtropical monsoon climate, with an annual average temperature of $19.9^{\circ} \mathrm{C}$, an extreme maximum temperature of $42{ }^{\circ} \mathrm{C}$, and a minimum temperature of $0{ }^{\circ} \mathrm{C}$. The annual average sunshine is 1 $755.4 \mathrm{~h}$, and the frost-free period is more than 360 days.

\section{Plant material and soil}

Two-year-old seedlings of $D$. latiflorus were grown in PVC pots with a diameter of $30 \mathrm{~cm}$ and a height of $33 \mathrm{~cm}$. The potting substrate material was yellow soil and peat (volume ratio 3:1) with a weight of $15 \mathrm{~kg}$

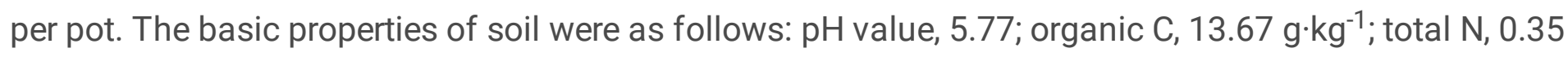
$\mathrm{g} \cdot \mathrm{kg}^{-1}$; total phosphorus $(\mathrm{P}), 0.50 \mathrm{~g} \cdot \mathrm{kg}^{-1}$; total potassium $(\mathrm{K}), 50.01 \mathrm{~g} \cdot \mathrm{kg}^{-1}$. The basic growth attributes of $D$. latiflorus Munro seedlings cultured from October 2018 were as follows: mean height, $105.51 \mathrm{~cm}$; mean DBH, $4.67 \mathrm{~mm}$; north-south crown, $71.11 \mathrm{~cm}$; east-west crown, $68.95 \mathrm{~cm}$.

\section{Experiment design}

In the current research, we used five N treatment combinations; N0, N1, N2, N3, and N4, like 0, 1.5, 3, 4.5, 6, $7.5 \mathrm{~g}$ of $\mathrm{N}$ in each pot, respectively. $\mathrm{N}$ was applied three times such as April (30\%), May (40\%), and June (30\%) 2019, respectively. The amount of exogenous $\mathrm{N}$ applied to the seedlings of $D$. latiflorus Munro seedlings has been presented in Table 1. All treatments were replicated 15 times. Leaf gas exchange parameters were measured after six months, after that, the leaf tissues were collected for the estimation of chlorophyll content, $\mathrm{N}$-related indices, and $\mathrm{C}$ content. Soil samples were also collected to measure Nrelated indices and $\mathrm{C}$ content. 
Urea (mass fraction 46\%) was applied as $\mathrm{N}$ fertilizer, calcium superphosphate $\left(\mathrm{P}_{2} \mathrm{O}_{5}\right.$, mass fraction $12 \%$ ), and potassium chloride $\left(\mathrm{K}_{2} \mathrm{O}\right.$, mass fraction $\left.60 \%\right)$ were used as phosphate and potassium fertilizer, respectively. Among them, phosphate and potassium fertilizer were applied only once, and the dosages were 6 and $1.5 \mathrm{~g} \cdot$ pot $^{-1}$, respectively. Weeding and other cultural practices were carried out regularly during the entire experiment.

\section{Investigation of the bamboo shoots}

After every two days, the number of shoots from each replicate was recorded from beginning to end. The bamboo shoots were harvest after they attained a height of approximately $50 \mathrm{~cm}$.

\section{Determination of leaf gas exchange parameters and chlorophyll content}

Li-6400 photosynthesis system (Li-Cor Inc., Lincoln, USA) was used to determine the gas exchange parameters [leaf net photosynthetic rate $\left(P_{\mathrm{n}}\right)$, stomatal conductance $\left(\right.$ Cond), intercellular $\mathrm{CO}_{2}$ concentration $\left(C_{\mathrm{i}}\right)$, transpiration rate $\left(T_{\mathrm{r}}\right)$, and water use efficiency (WUE)] from 2-3 mature functional leaves during consecutive sunny days. The LED (red and blue) light source was used with $1600 \mu \mathrm{mol} \cdot \mathrm{m}^{-}$ $2 . s^{-1}$ photosynthetically active radiation (PAR). The readings were collected from all replicates, however, before the measurement, the sampling leaves were induced under a light intensity of $1600 \mu \mathrm{mol} \cdot \mathrm{m}^{-2} \cdot \mathrm{s}^{-1}$ PAR for 20-30 min.

Following the assessment of gas exchange parameters, fresh leaves were cut to determine the concentrations of the photosynthetic pigments. After the separation of the midrib, the fresh leaves were cut into pieces and weighed $0.2 \mathrm{~g}$. A mixed solution (pure acetone: absolute ethanol: distilled water $=4.5$ : 4.5:1) of $25 \mathrm{ml}$ (Gao 2006) was used to extract the photosynthetic pigments directly in the dark for $48 \mathrm{~h}$. Chlorophyll a (Chl a), b (Chl b), total content (Chls), and carotenoid (Car) contents were calculated by optical density (OD) values according to the equations of Lichtenthaler (Lichtenthaler 1987), and the ratios of $\mathrm{Chl} \mathrm{a/b}$ and Car/Chls were further calculated.

\section{Determination of leaf $\mathrm{N}$ Indices and $\mathrm{C}$ content}

After the extraction of leaf chlorophyll, part of fresh leaves was chopped, mixed, weighed, stored in liquid $\mathrm{N}$, and then stored at $-80^{\circ} \mathrm{C}$ refrigerator for measuring. Fresh leaves were used to estimate the glutamine

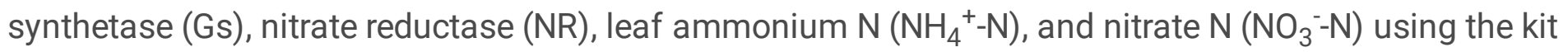
manufactured by Suzhou Keming Biotechnology Co., Ltd. After chopping and mixing, another part of fresh leaves was oven-dried at $105^{\circ} \mathrm{C}$ for 15 minutes and later at $85^{\circ} \mathrm{C}$ to dry to constant weight. Furthermore, the dried samples were grinded with an ultra-high-speed pulverizer (HUANGCHENG HC-300Y, China) and sieved through a $0.149 \mathrm{~mm}$ sieve. The total $\mathrm{C}$ and $\mathrm{N}$ contents were determined using an element analyzer (VARIO MAX, ELEMENTAR, Germany), and their ratio was further calculated.

\section{Determination of soil $\mathrm{C}$ and $\mathrm{N}$ indices}


Similarly, the fresh soil samples were taken from a distance of $10 \mathrm{~cm}$ and a depth of $10 \mathrm{~cm}$ around the bamboo stump. After removing stones and roots, each soil sample was separated into two portions: One portion was used to determine soil $\mathrm{NH}_{4}{ }^{+}-\mathrm{N}$ and $\mathrm{NO}_{3}{ }^{-} \mathrm{N}$ using the chemical kits. The other was air-dried, grinded, and sieved to $0.149 \mathrm{~mm}$ to determine total $\mathrm{C}$ and $\mathrm{N}$ contents using an element analyzer (VARIO MAX, ELEMENTAR, Germany), and their ratios were also calculated.

\section{Data Analysis}

All the data were expressed as means and standard errors. Analysis of variance (one-way ANOVA) was performed using SPSS 20.0 to determine the effect of $\mathrm{N}$ treatments, and Tukey HSD test was used to identify significant differences $(\alpha=0.05)$ between mean values. Origin 9.5 and Prism 8.0 were used for graphical illustrations.

Table 1: The amount of exogenous $\mathrm{N}\left(\mathrm{g} \cdot \mathrm{pot}^{-1}\right)$ applied to $D$. latiflorus Munro seedlings.

\begin{tabular}{|lllllll|}
\hline \multirow{2}{*}{ Fertilization times } & \multicolumn{7}{l|}{ Treatments $\left(\mathrm{g} \cdot \mathrm{pot}^{-1}\right)$} & & & \\
\cline { 2 - 7 } & $\mathrm{CK}$ & $\mathrm{N} 1$ & $\mathrm{~N} 2$ & $\mathrm{~N} 3$ & $\mathrm{~N} 4$ & $\mathrm{~N} 5$ \\
\hline$\square$ & 0 & 0.45 & 0.90 & 1.35 & 1.80 & 2.25 \\
$\square$ & 0 & 0.60 & 0.12 & 1.80 & 2.40 & 3.00 \\
$\square$ & 0 & 0.45 & 0.90 & 1.35 & 1.80 & 2.25 \\
\hline Total amount & 0 & 1.50 & 3.00 & 4.50 & 6.00 & 7.50 \\
\hline
\end{tabular}

\section{Results}

\section{Impact of $\mathrm{N}$ application on bamboo shoots}

We noticed that $\mathrm{N}$ application significantly influenced the number of bamboo shoots (Figure 2). $D$. latiflorus Munro established under N4 treatments increased their shoots up to $68.75 \%(P \otimes 0.05)$ compared to NO.

\section{Leaf photosynthetic pigments concentrations under various $\mathrm{N}$ application rates}

Under various $\mathrm{N}$ application rates, the leaves photosynthetic pigments (Car, Chls, and $\mathrm{Chl} \mathrm{a/b)}$ concentrations increased as depicted in Figure 3. Compared to N0, under N4 and N5, the increases of $100 \%$ and $109.60 \%, 99.08 \%$ and $110.52 \%, 14.01 \%$ and $13.13 \%(P \otimes 0.05)$ were observed for Chls, Car, and $\mathrm{Chl}$ a/b, respectively (Figure $3 \mathrm{~A}-\mathrm{C}$ ). Besides, for Car/Chls ratio, compared to N0, seedlings established under the $\mathrm{N}$ application did not show any difference (Figure 3D).

\section{Leaf gas exchange parameters under various $\mathbf{N}$ application rates}


The $\mathrm{N}$ application had a significant ( $P \otimes 0.05)$ effect on leaf $P_{\mathrm{n}}$ (Figure 4A). Specifically, N4 and N5 treatments resulted in a significant rise in leaf $P_{\mathrm{n}}$ relative to N0, whereas $\mathrm{N} 4$ was found the most effective over all other treatments combinations. In addition, the rise in Cond was parallel to the $\mathrm{N}$ application rate (Figure 4B) and seedlings established under N4 greatly ( $P \otimes 0.05)$ enhanced their plant Cond $(106.57 \%)$ as compared to NO. In contrast, compared to NO, none of $\mathrm{N}$ based treatments influenced the $C_{\mathrm{i}}$ and $T_{\mathrm{r}}$ significantly (Figure 4C, D). Besides, seedlings under N4 exhibited a relatively greater WUE compared to all other treatments (Figure 4E).

\section{The $\mathrm{N}$ and $\mathrm{C}$ indices of leaf and soil under various $\mathrm{N}$ application rates}

Compared to N0, N treated seedlings accumulated significantly $(P \otimes 0.05)$ greater soil $\mathrm{N}$ and $\mathrm{C}$ contents (Figure 5). Overall, N4 treated seedlings responded with maximum concentrations for leaf $\mathrm{N}$ and $\mathrm{C}$

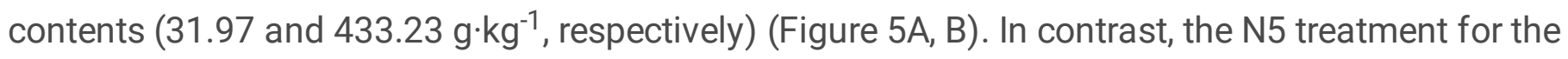
contents of soil $\mathrm{N}$ and $\mathrm{C}$ were higher relative to other treatments (Figure 5D, E). Except for N5, the leaf $\mathrm{C} / \mathrm{N}$ ratio decreased under $\mathrm{N}$ application as the level of concentration increased (Figure 5C). Additionally, seedlings amended with $\mathrm{N} 4$ treatment responded with maximum soil $\mathrm{C} / \mathrm{N}$ ratio (Figure $5 \mathrm{~F}$ ).

\section{Leaf GS and NR activities under various $\mathrm{N}$ application rates}

The activities of leaf GS and NR were highly influenced by N application (Figure 6). Compared to N0, GS activities greatly $(P \otimes 0.05)$ increased by $140.55 \%$ and $121.13 \%$ under N3 and N4 treatments (Figure $6 \mathrm{~A})$. N application showed no significant impact on NR activities, while N3 and N4 enhanced NR activities by $82.73 \%$ and $70.43 \%$, respectively, when compared to N0 (Figure 6B).

\section{Leaf and soil $\mathrm{NH}_{4}{ }^{+}-\mathrm{N}$ and $\mathrm{NO}_{3}{ }^{-}-\mathrm{N}$ under various $\mathrm{N}$ application rates}

$\mathrm{N}$ application determined higher leaf $\mathrm{NH}_{4}{ }^{+} \mathrm{N}$ in seedlings compared to $\mathrm{N} 0$ (Figure 7A). N1, N2, and N3 treatments showed a significant ( $P \otimes 0.05$ ) impact on soil $\mathrm{NH}_{4}{ }^{+}-\mathrm{N}$, while $\mathrm{N} 4$ decreased soil $\mathrm{NH}_{4}{ }^{+}-\mathrm{N}$ by $18.88 \%$ compared to NO (Figure $7 \mathrm{C}$ ). In contrast, there was a decline under $\mathrm{N}$ application amended seedlings for leaf and soil $\mathrm{NO}_{3}{ }^{-}-\mathrm{N}$ (Figure $\left.7 \mathrm{~B}, \mathrm{D}\right)$.

\section{Evaluation of all indices under different $\mathrm{N}$ treatments by principal component analysis (PCA)}

Principle component analysis (PCA) revealed that the cumulative variance contribution rate of the first two principal components reached $74.47 \%$, suggesting an overall variation of the data (Fig. 8). PC1 showed that the number of shoots had a highly positive correlation with photosynthetic pigments (Car, Chls, and $\mathrm{Chl} \mathrm{a/b})$, gas exchange parameters $\left(P_{\mathrm{n}}\right.$, Cond, $T_{\mathrm{r}}$, and WUE), and $\mathrm{C}$ and $\mathrm{N}$ metabolism related indices (GS, NR, LC, $\mathrm{LN},{\mathrm{L}-\mathrm{NH}_{4}}^{+}$, and $\mathrm{S}-\mathrm{NH}_{4}{ }^{+}$). Except for $\mathrm{LC} / \mathrm{N}, \mathrm{S}-\mathrm{NO}_{3}{ }^{-}$, and $\mathrm{S}-\mathrm{NO}_{3}{ }^{-}$, all indices exhibited with PC1 were favorable following N4 treatment, whereas $\mathrm{N} 0$ was negatively correlated with $\mathrm{LC} / \mathrm{N}, \mathrm{S}^{-} \mathrm{NO}_{3}{ }^{-}$, and $\mathrm{S}^{-\mathrm{NO}_{3}}$. 


\section{Discussion}

In the current study, we noticed that different $\mathrm{N}$ levels impacted the number of shoots, leaf photosynthetic characteristics, soil and leaf $\mathrm{N}$-related indices in $D$. latiflorus Munro seedlings. The optimal $\mathrm{N}$ application can substantially increase leaf $\mathrm{N}$ and photosynthetic pigments, as well as improve plant photosynthetic efficiency and leaf physiological activities (Peng et al. 2021). The increase in soil $\mathrm{C}$ and $\mathrm{N}$ contents is conducive to the accumulation of leaf chlorophyll content, improving leaf photosynthetic capacity, and accelerate $C$ and $N$ metabolism and conversion (Manna et al. 2005, Zhang et al. 2019) ultimately increasing the number of shoots, which was also confirmed by our research.

The formation of bamboo shoots is inseparable from the intensity of photosynthesis, $\mathrm{N}$ utilization, and transportation (Dordas \& Sioulas 2008). Increasing the application of $\mathrm{N}$ fertilizer up to some extent may increase the chlorophyll contents, prolong the function period of the leaves, and improve the photosynthetic efficiency, thereby increasing the production capacity of the plant (Liu et al. 2019a, Fu et al. 2020a). The current study concluded that $\mathrm{N}$ application enhanced the chlorophyll accumulation and improved the photosynthetic efficiency in leaves (Figures 3, 4). For instance, N4 treatment had a positive effect on the accumulation of leaf chlorophylls and $P_{\mathrm{n}}$ in leaves (Figures 3,4 ), indicating that optimal $\mathrm{N}$ supply can effectively increase leaf chlorophyll contents, which was conducive to improving the photosynthesis mechanism of $D$. latiflorus Munro seedlings.

In plants, nutrient elements play a vital role in maintaining leaf $\mathrm{C}$ balance and sustaining photosynthetic efficiency (Matthews et al. 2017). In the current research, $\mathrm{N}$ application significantly increased $P_{\mathrm{n}}$ to fix relatively large amounts of $C$ for photosynthesis (Figure $4 A$ ), which is closely related to $N$ assimilation and metabolic processes (Huang et al. 2013, Zhang et al. 2017). We reported that N4 was advantageous compared to other $\mathrm{N}$ treatments in terms of increasing $P_{\mathrm{n}}$ to enhance the $\mathrm{C}$ sequestration ability of $D$. latiflorus Munro (Figure 4A). Higher Cond leads to enhancing leaf photosynthetic biochemical pathways and the accumulation of photosynthetic products (Lichtenthaler et al. 2007a, Lichtenthaler et al. 2007b). Compared with NO, the values of Cond, $C_{\mathrm{i}}, T_{\mathrm{r}}$, and WUE increased in a certain degree of $\mathrm{N}$ treatments (Figure 4B-D), which can improve photosynthetic performance in the growth of D. latiflorus Munro.

$\mathrm{N}$ application can effectively increase the contents and reserves of soil organic $\mathrm{C}$ and total $\mathrm{N}$ content (Huang et al. 2013). The C: $\mathrm{N}$ ratio in the soil can reflect the utilization efficiency of the soil, and the application of fertilizer can affect the nutrient element in the soil (Vitousek 1982). In our research, $\mathrm{N}$ treatments significantly improved $\mathrm{N}$ availability and increased soil $\mathrm{N}$ contents (Figure 5D). Similarly, $\mathrm{N}$ provided a carbon source and improved environment in the soil, which promoted the conversion of organic $C$ and increased the organic $C$ content (Cheng et al. 2020), where all $N$ treatments significantly increased soil C content compared to N0 (Figure 5E). Additionally, previous studies have shown that there is a positive correlation between soil $\mathrm{C}$ and $\mathrm{N}$ content and crop yield (Wang et al. 2019, Zhang et al. 2019). Our research found that shoot, SC, and SN all had positive correlations (Figure 8). 
In addition, some studies have shown that the application of $\mathrm{N}$ fertilizer significantly increases the $\mathrm{N}$ accumulation in leaves, thereby reducing the $C$ to $N$ ratio of the leaves (Liu et al. 2014, Wu et al. 2019), which are consistent with our research (Figure $5 \mathrm{~A}-\mathrm{C}$ ). These changes would be conducive to increasing productivity, as well as changing the degradation and mineralization of leaves, which in turn would be conducive to the return of $C$ and $N$ to the soil (Stubbs et al. 2009, Pierik et al. 2011), to ensure the supply essential nutrient to meet the needs of bamboo shoot production.

NR and GS are the key enzymes for $\mathrm{N}$ assimilation and ammonia assimilation in plant physiological processes (Xie et al. 2014, Lin et al. 2017). Zhu et al. (2016) found that fertilization can effectively promote the N metabolism of Phyllostachys edulis, and enhance the activities of both NR and GS, which is related to the direct promotion of fertilizers and the absorption of $\mathrm{N}$ by plants. Our research came to the same conclusion that the activities of NR and GS were enhanced with the application of $\mathrm{N}$ fertilization (Figure 6), which can improve transformation of $\mathrm{N}$ metabolism directly. Furthermore, $\mathrm{N}$ application would encourage plants to absorb more $\mathrm{N}$ to synthesize more NR and GS indirectly.

Compared to $\mathrm{NO}$, the soil and leaf $\mathrm{NH}_{4}{ }^{+}-\mathrm{N}$ was at a significant level under $\mathrm{N}$ supply (Figure 7). Soil $\mathrm{NH}_{4}{ }^{+}-\mathrm{N}$ was greatly reduced under $\mathrm{N} 4$ treatment with comparison to $\mathrm{NO}_{3}{ }^{-} \mathrm{N}$ (Figure $7 \mathrm{C}, \mathrm{D}$ ), indicating that roots of seedlings had higher absorption of $\mathrm{NH}_{4}{ }^{+} \mathrm{N}$. The enhanced $\mathrm{NR}$ activity under $\mathrm{N}$ application could promote the reduction of $\mathrm{NO}_{3}{ }^{-}$to more $\mathrm{NH}_{4}{ }^{+}$(Maeda et al. 2014), which possibly promoted to accumulation of $\mathrm{NH}_{4}{ }^{+}-\mathrm{N}$ of leaves in our research (Figures $6 \mathrm{~B}, 7 \mathrm{~A}$ ). Additionally, compared with other $\mathrm{N}$ treatments, the enhanced activity of GS under $\mathrm{N} 4$ treatment could be conducive to catalyzing inorganic $\mathrm{NH}_{4}{ }^{+}-\mathrm{N}$ to producing more organic $\mathrm{N}$ (Figure $6 \mathrm{~A}$ ), which could provide sufficient $\mathrm{N}$ not only for bamboo shoot production but also to synthesize more chlorophyll to ensure the photosynthesis of seedlings (Cruz et al. 1993). However, $\mathrm{NO}_{3}{ }^{-} \mathrm{N}$ of soil and leaves had an insignificant negative correlation with bamboo shoots (Figure 8), which had an adverse effect on shoots. Our research was consistent with the previous findings that $\mathrm{NH}_{4}{ }^{+}-\mathrm{N}$ can promote leaf chlorophyll synthesis and increase plant production (Sanchez-Zabala et al. 2015, Heuermann et al. 2021).

The PCA analyzed with strong correlations may be screened out and can be used to assess $D$. latiflorus Munro adaptation to varying $\mathrm{N}$ levels. According to the PCA results, N4 treatment seems to be advantageous for shoots growth (Figures 2,8), owing to increased leaf photosynthetic characteristics and soil nutrients availability. In addition, the increased number of bamboo shoots under N4 treatment exhibited strong correlations with chlorophylls pigments and leaf N-related indices (Figure 8), which may regulate the photosynthesis mechanism and promote $\mathrm{N}$ accumulation in $D$. latiflorus Munro to fulfill the requirements of a greater number of bamboo shoots.

\section{Conclusions}

Exogenous $\mathrm{N}$ has varying degrees of influence on the photosynthetic characteristics, nutritional element contents, and $\mathrm{N}$ metabolism-related indices of $D$. latiflorus Munro seedlings. We conclude that applying $\mathrm{N}$ 
fertilizer $\left(6 \mathrm{~g} \cdot \mathrm{pot}^{-1}\right)$ to maximize the growth and shoot production of $D$. latiflorus Munro seedlings is advantageous. We elucidated the $\mathrm{N}$ absorption mechanism of the bamboo seedlings as well as the related physiological change mechanism after the application of $\mathrm{N}$ fertilizer. These findings not only provide a theoretical basis for improving the $\mathrm{N}$ utilization efficiency of $D$. latiflorus Munro but also the production of high-yield and high-quality bamboo shoots in the future.

\section{Declarations}

\section{Availability of data and materials}

The data and materials presented in this study have been available in the article.

\section{Competing interests}

The authors declare that they have no competing interests

\section{Funding}

This work was supported by the "National Key R\&D Program of China" (2018YFD0600100); program for scientific and technological innovation teams for universities of Fujian province (No.2018[49]).

\section{Authors' contributions}

LLF performed all the experiments, analyzed the data, and wrote the manuscript. MWKT revised the manuscript. YZH and WFH helped in performing the experiments. JDR and TYH helped in designing the study. YSZ designed and directed the study. All authors have read and approved the final manuscript.

\section{Acknowledgments}

The authors would like to express their gratitude to the anonymous reviewers who provided useful feedback and suggestions on this article.

\section{References}

Bargaz A, Lyamlouli K, Chtouki M, Zeroual Y, Dhiba D (2018). Soil microbial resources for improving fertilizers efficiency in an integrated plant nutrient management system. Frontiers in Microbiology. 9. - doi: $10.3389 /$ fmicb.2018.01606

Cheng C, Wu Z, Huang Q, Han C, Zhong W (2020). Effect of organic matter promotion on nitrogen-cycling genes and functional microorganisms in acidic red soils. Environmental Science. 41: 2468-2475. - doi: 10.13227/j.hjkx.201911013.

Cruz C, Lips SH, Martins-Loucao MA (1993). The effect of nitrogen source on photosynthesis of carob at high CO2 concentrations. Physiologia Plantarum. 89: 552-556. - doi: 10.1111/j.1399- 
Dordas CA, Sioulas C (2008). Safflower yield, chlorophyll content, photosynthesis, and water use efficiency response to nitrogen fertilization under rainfed conditions. Industrial Crops and Products. 27: 75-85. - doi: 10.1016/j.indcrop.2007.07.020

Forde B, Lorenzo H (2002). The nutritional control of root development. In: Interactions in the Root Environment: An Integrated Approach. Springer Netherlands, Dordrecht. - doi: 10.1007/978-94-010-0566$1 \_6$

Fu W, Wang Y, Ye Y, Zhen S, Zhou B, Wang Y, Hu Y, Zhao Y, Huang Y (2020a). Grain yields and nitrogen use efficiencies in different types of stay-green maize in response to nitrogen fertilizer. Plants. 9: 474. - doi: $10.3390 /$ plants 9040474

Fu Y, Zhang Z, Yang X, Wang C, Lan T, Tang X, Chen G, Zeng J, Yuan S (2020b). Nitrate reductase is a key enzyme responsible for nitrogen-regulated auxin accumulation in Arabidopsis roots. Biochemical and Biophysical Research Communications. 532: 633-639. - doi: 10.1016/j.bbrc.2020.08.057

Gao J (2006). Experimental guide of plant physiology., pp. 76.

Gao P, Zuo Z, Zhang R, Qiu Y, He R, Gao R, Gui R (2016). Optimum nitrogen fertilization for Phyllostachys edulis productivity and photosynthetic response. Agronomy Journal. 108: 448-458. - doi: 10.2134/agronj2015.0324

Heuermann D, Hahn H, von Wirén N (2021). Seed yield and nitrogen efficiency in oilseed rape after ammonium nitrate or urea fertilization. Frontiers in Plant Science. 11. - doi: 10.3389/fpls.2020.608785

Huang W, Siemann E, Yang X, Wheeler GS, Ding J (2013). Facilitation and inhibition: changes in plant nitrogen and secondary metabolites mediate interactions between above-ground and below-ground herbivores. Proceedings of the Royal Society B: Biological Sciences. 280: 20131318. - doi:

$10.1098 /$ rspb.2013.1318

Kataria S, Guruprasad KN (2015). Exclusion of solar UV radiation improves photosynthetic performance and yield of wheat varieties. Plant Physiology and Biochemistry. 97: 400-411. - doi:

10.1016/j.plaphy.2015.10.001

Kirova E, Nedeva D, Nikolova A, Ignatov G (2005). Changes in the biomass production and total soluble protein spectra of nitrate-fed and nitrogen-fixing soybeans subjected to gradual water stress. Plant, Soil and Environment. 51: 237-242.

Kishorekumar R, Bulle M, Wany A, Gupta KJ (2020a). An overview of important enzymes involved in nitrogen assimilation of plants. In: Methods in molecular biology. - doi: 10.1007/978-1-4939-9790-9_1 
Kishorekumar R, Bulle M, Wany A, Gupta KJ (2020b). An overview of important enzymes involved in nitrogen assimilation of plants. In: Methods in molecular biology. - doi: 10.1007/978-1-4939-9790-9_1

Kleinhenz V, Milne J, Walsh KB, Midmore DJ (2003). A case study on the effects of irrigation and fertilization on soil water and soil nutrient status, and on growth and yield of bamboo (Phyllostachys pubescens) shoots. Journal of Bamboo \& Rattan (VSP International Science Publishers).

Krapp A, Castaings L (2012). Réponses des plantes à la disponibilité en azote. Biologie Aujourd'hui. 206: 323-335. - doi: 10.1051/jbio/2012031

Krouk G, Crawford NM, Coruzzi GM, Tsay Y-F (2010). Nitrate signaling: adaptation to fluctuating environments. Current Opinion in Plant Biology. 13: 265-272. - doi: 10.1016/j.pbi.2009.12.003

Kurai T, Wakayama M, Abiko T, Yanagisawa S, Aoki N, Ohsugi R (2011). Introduction of the ZmDof1 gene into rice enhances carbon and nitrogen assimilation under low-nitrogen conditions. Plant Biotechnology Journal. 9: 826-837. - doi: 10.1111/j.1467-7652.2011.00592.x

Li Q, Peng C, Wu J, Hänninen H, Yao H, Zhang R, Song X, Ying Y (2017). Nitrogen Deposition Enhances Photosynthesis in Moso Bamboo but Increases Susceptibility to Other Stress Factors. Frontiers in Plant Science. 8: 1-11. - doi: 10.3389/fpls.2017.01975

Lichtenthaler HK (1987). Chlorophylls and carotenoids: pigments of photosynthetic biomembranes. Methods in Enzymology. 148: 350-382.

Lichtenthaler HK, Ač A, Marek M V, Kalina J, Urban O (2007a). Differences in pigment composition, photosynthetic rates and chlorophyll fluorescence images of sun and shade leaves of four tree species. Plant Physiology and Biochemistry. 45: 577-588. - doi: 10.1016/j.plaphy.2007.04.006

Lichtenthaler HK, Fatbardha B, Gabriele L (2007b). Chlorophyll fluorescence imaging of photosynthetic activity in sun and shade leaves of trees. Photosynthesis Research. 93: 235-244. - doi: 10.1007/s11120007-9174-0

Lin Y, Zhang J, Gao W, Chen Y, Li H, Lawlor DW, Paul MJ, Pan W (2017). Exogenous trehalose improves growth under limiting nitrogen through upregulation of nitrogen metabolism. BMC Plant Biology. 17: 247. - doi: 10.1186/s12870-017-1207-z

Liu C-W, Sung Y, Chen B-C, Lai H-Y (2014). Effects of nitrogen fertilizers on the growth and nitrate content of Lettuce (Lactuca sativa L.). International Journal of Environmental Research and Public Health. 11: 4427-4440. - doi: 10.3390/ijerph110404427

Liu N, Zhang S, Huang Y, Cai H, Zhu X (2020). Understory and canopy additions of nitrogen differentially affect carbon and nitrogen metabolism of Psychotria rubra in an evergreen broad-leaved forest. Science of The Total Environment. 724: 138183. - doi: 10.1016/j.scitotenv.2020.138183 
Liu Z, Gao F, Yang J, Zhen X, Li Y, Zhao J, Li J, Qian B, Yang D, Li X (2019a). Photosynthetic characteristics and uptake and translocation of nitrogen in peanut in a wheat-peanut rotation system under different fertilizer management regimes. Frontiers in Plant Science. 10. - doi: $10.3389 /$ fpls.2019.00086

Liu Z, Gao F, Yang J, Zhen X, Li Y, Zhao J, Li J, Qian B, Yang D, Li X (2019b). Photosynthetic characteristics and uptake and translocation of nitrogen in peanut in a wheat-peanut rotation system under different fertilizer management regimes. Frontiers in Plant Science. 10. - doi: $10.3389 /$ fpls.2019.00086

Maeda S, Konishi M, Yanagisawa S, Omata T (2014). Nitrite transport activity of a novel HPP family protein conserved in cyanobacteria and chloroplasts. Plant and Cell Physiology. 55: 1311-1324. - doi: 10.1093/pcp/pcu075

Manna MC, Swarup A, Wanjari RH, Ravankar HN, Mishra B, Saha MN, Singh YV, Sahi DK, Sarap PA (2005). Long-term effect of fertilizer and manure application on soil organic carbon storage, soil quality and yield sustainability under sub-humid and semi-arid tropical India. Field Crops Research. 93: 264-280. - doi: 10.1016/j.fcr.2004.10.006

Matthews JSA, Vialet-Chabrand SRM, Lawson T (2017). Diurnal variation in gas exchange: The balance between carbon fixation and water Loss. Plant Physiology. 174: 614-623. - doi: 10.1104/pp.17.00152

Mu X, Chen Y (2021). The physiological response of photosynthesis to nitrogen deficiency. Plant Physiology and Biochemistry. 158: 76-82. - doi: 10.1016/j.plaphy.2020.11.019

O’Brien JA, Vega A, Bouguyon E, Krouk G, Gojon A, Coruzzi G, Gutiérrez RA (2016). Nitrate transport, sensing, and responses in plants. Molecular Plant. 9: 837-856. - doi: 10.1016/j.molp.2016.05.004

Peng J, Feng Y, Wang X, Li J, Xu G, Phonenasay S, Luo Q, Han Z, Lu W (2021). Effects of nitrogen application rate on the photosynthetic pigment, leaf fluorescence characteristics, and yield of indica hybrid rice and their interrelations. Scientific Reports. 11: 7485. - doi: 10.1038/s41598-021-86858-z

Pierik M, Ruijven J V, Bezemer TM, Geerts R, Berendse F (2011). Recovery of plant species richness during long-term fertilization of a species-rich grassland. Ecology. 92: 1393-1398.

Sanchez-Zabala J, González-Murua C, Marino D (2015). Mild ammonium stress increases chlorophyll content in Arabidopsis thaliana. Plant Signaling \& Behavior. 10: e991596. - doi:

10.4161/15592324.2014.991596

Scheible WR, Gonzalez-Fontes A, Lauerer M, Muller-Rober B, Caboche M, Stitt M (1997). Nitrate acts as a signal to induce organic acid metabolism and repress starch metabolism in Tobacco. The Plant Cell. 15: 783-798. - doi: 10.1105/tpc.9.5.783 
Seabra AR, Carvalho HG (2015). Glutamine synthetase in medicago truncatula, unveiling new secrets of a very old enzyme. Frontiers in Plant Science. 6. - doi: 10.3389/fpls.2015.00578

Stitt M (1999). Nitrate regulation of metabolism and growth. Current Opinion in Plant Biology. 2: 178186. - doi: 10.1016/S1369-5266(99)80033-8

Stubbs TL, Kennedy AC, Reisenauer PE, Burns JW (2009). Chemical composition of residue from cereal crops and cultivars in dryland ecosystems. Agronomy Journal. 101: 538-545. - doi:

10.2134/agronj2008.0107x

Talukder P, Dedkova LM, Ellington AD, Yakovchuk P, Lim J, Anslyn E V., Hecht SM (2016). Synthesis of alanyl nucleobase amino acids and their incorporation into proteins. Bioorganic \& Medicinal Chemistry. 24: 4177-4187. - doi: 10.1016/j.bmc.2016.07.008

Vitousek P (1982). Nutrient cycling and nutrient use efficiency. The American Naturalist. 119: 553-572. doi: $10.1086 / 283931$

Walch-Liu P, Neumann G, Bangerth F, Engels C (2000). Rapid effects of nitrogen form on leaf morphogenesis in tobacco. Journal of Experimental Botany. 51: 227-237. - doi:

$10.1093 /$ jexbot/51.343.227

Wang T, Ding N, Li L, Zhou H, Shang L (2019). Combining chemical fertilizer with organic manure or straw increase the yield stability and sustainability of maize and wheat in Loess Plateau of east Gansu Province. Journal of Plant Nutrition and Fertilizers. 25: 1817-1826.

Wen B, Xiao W, Mu Q, Li D, Chen X, Wu H, Li L, Peng F (2020). How does nitrate regulate plant senescence? Plant Physiology and Biochemistry. 157: 60-69. - doi: 10.1016/j.plaphy.2020.08.041

Wu Y, Zhao B, Li Q, Kong F, Du L, Zhou F, Shi H, Ke Y, Liu Q, Feng D, Yuan J (2019). Non-structural carbohydrates in maize with different nitrogen tolerance are affected by nitrogen addition. PLoS ONE. 14: 1-19. - doi: 10.1371/journal.pone.0225753

Xie J, Bai X, Li Y, Sun C, Qian H, Fu Z (2014). The effect of glufosinate on nitrogen assimilation at the physiological, biochemical and molecular levels in Phaeodactylum tricornutum. Ecotoxicology. 23: 14301438. - doi: 10.1007/s10646-014-1285-8

Xing Y, Guo S, Chen X, Du D, Liu M, Xiao Y, Zhang T, Zhu M, Zhang Y, Sang X, He G, Wang N (2018). Nitrogen metabolism is affected in the nitrogen-deficient rice mutant es 14 with a calcium-dependent protein kinase gene mutation. Plant and Cell Physiology. - doi: 10.1093/pcp/pcy169

Xu S, Fu X, Ma S, Bai Z, Xiao R, Li Y, Zhuang G (2014). Mitigating nitrous oxide emissions from tea field soil using bioaugmentation with a trichoderma viride biofertilizer. The Scientific World Journal. 2014: 19. - doi: $10.1155 / 2014 / 793752$ 
Yang X, Nian J, Xie Q, Feng J, Zhang F, Jing H, Zhang J, Dong G, Liang Y, Peng J, Wang G, Qian Q, Zuo J (2016). Rice ferredoxin-dependent glutamate synthase regulates nitrogen-carbon metabolomes and is genetically differentiated between japonica and indica Subspecies. Molecular Plant. 9: 1520-1534. - doi: 10.1016/j.molp.2016.09.004

Zhang R, Wu J, Li Q, Hänninen H, Peng C, Yao H, Song X, Ying Y (2017). Nitrogen deposition enhances photosynthesis in moso bamboo but increases susceptibility to other stress factors. Frontiers in Plant Science. 8. - doi: 10.3389/fpls.2017.01975

Zhang XZ, Gao HJ, Peng C, Qiang LI, Zhu P, Gao Q (2019). Variation trend of soil organic carbon, total nitrogen and the stability of maize yield in black soil under long-term organic fertilization. Journal of Plant Nutrition and Fertilizers. 25: 1473-2532.

Zhou W, Lv T, Yang Z, Wang T, Fu Y, Chen Y, Hu B, Ren W (2017a). Morphophysiological mechanism of rice yield increase in response to optimized nitrogen management. Scientific Reports. 7: 17226. - doi: 10.1038/s41598-017-17491-y

Zhou W, Lv T, Yang Z, Wang T, Fu Y, Chen Y, Hu B, Ren W (2017b). Morphophysiological mechanism of rice yield increase in response to optimized nitrogen management. Scientific Reports. 7: 17226. - doi: 10.1038/s41598-017-17491-y

Zhu QG, Jin AW, Lou YH, Luo J (2016). Effect of fertilization on root acid phosphatase and nitrogen metabolism of Phyllostachys heterocycla cv. pubescens. Journal of Fujian Forestry Science and Technology.

Zhu Z, Chen D (2002). Nitrogen fertilizer use in China-contributions to food production, impacts on the environment and best management strategies. Nutrient Cycling in Agroecosystems. 63: 117-127. - doi: 10.1023/A:1021107026067

\section{Figures}




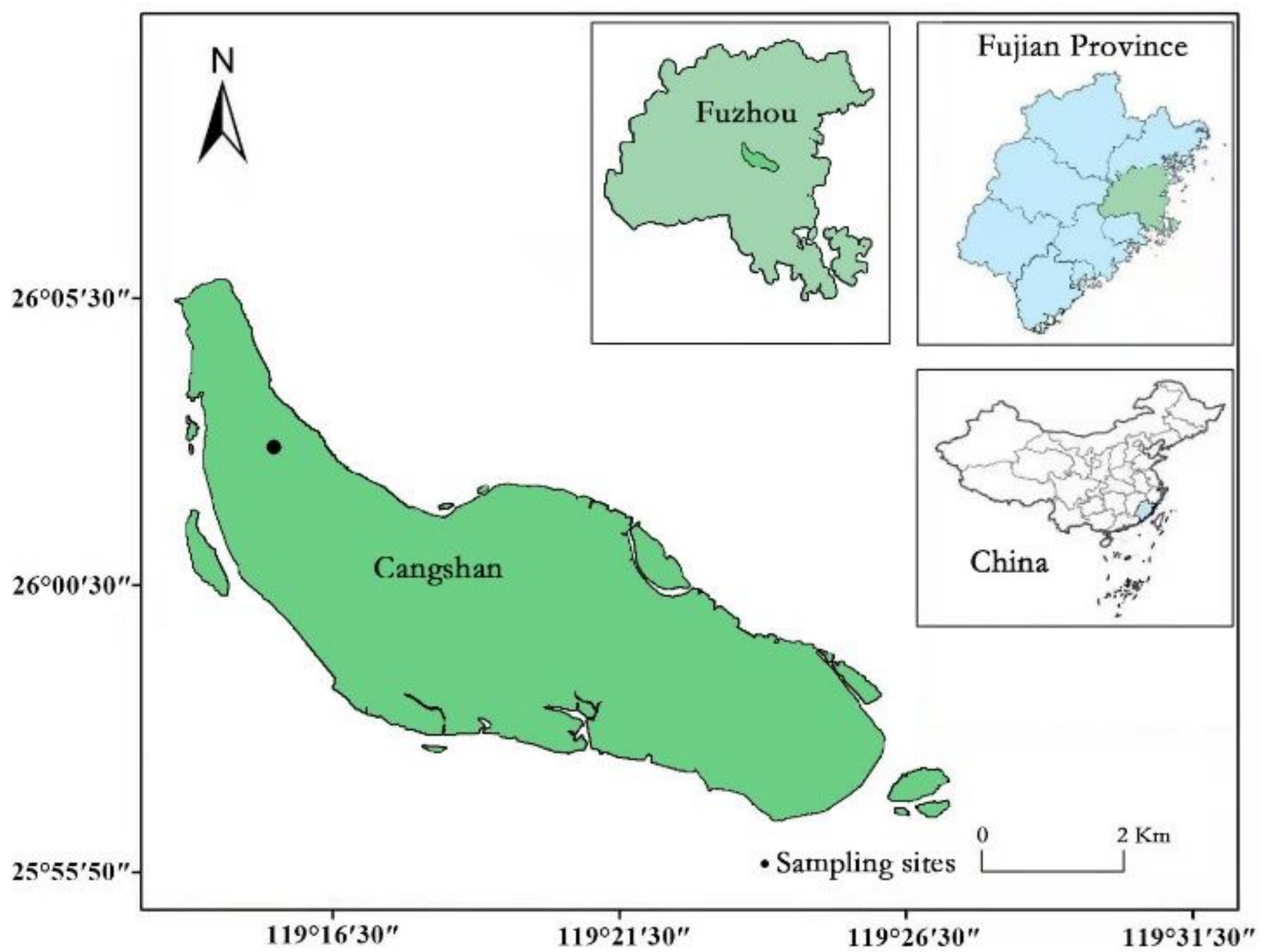

Figure 1

The geographical location of Fujian Agriculture and Forestry University. 


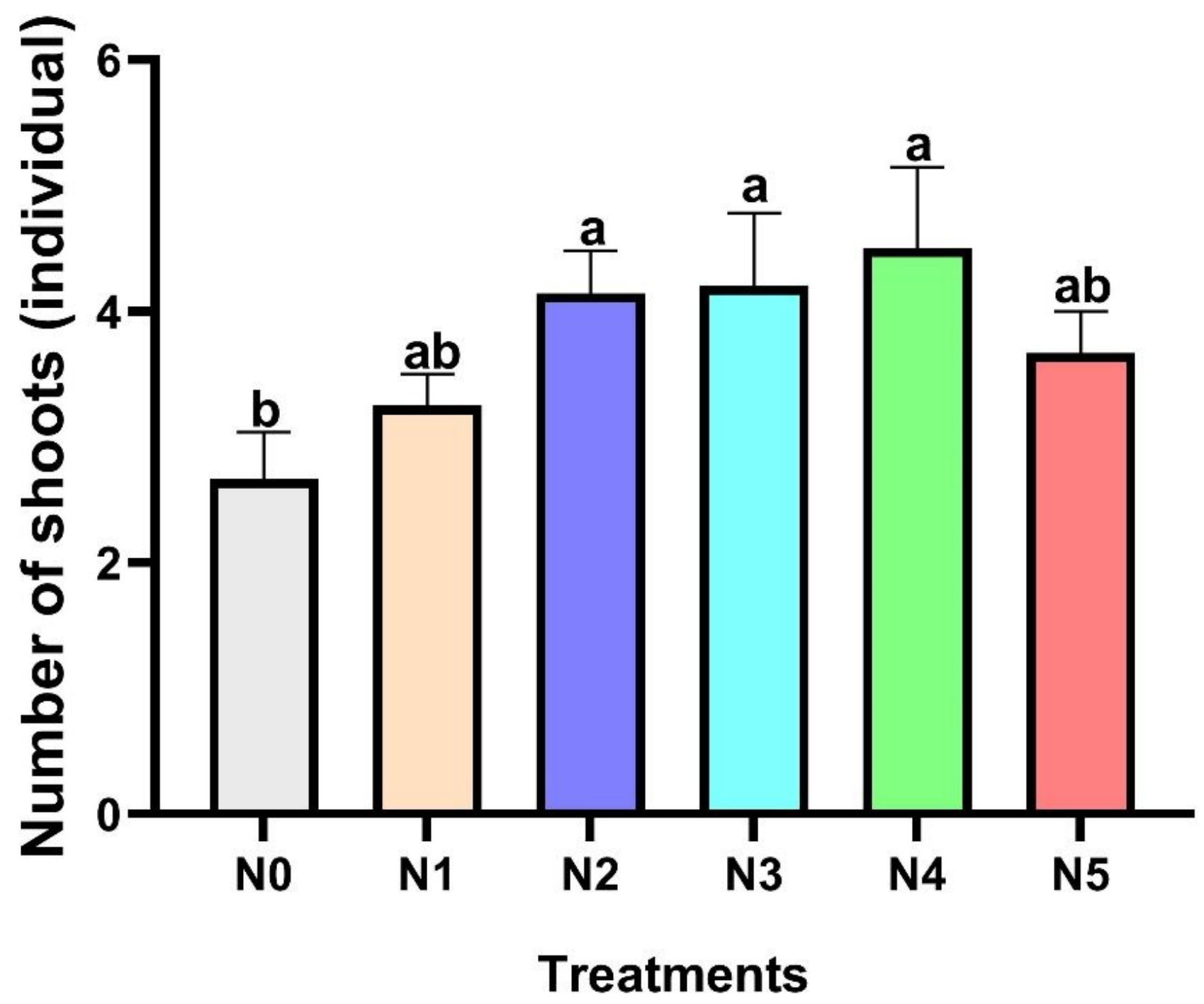

Figure 2

The number of bamboo shoots under various $N$ application rates. N1: $1.50 \mathrm{~g} \cdot$ pot-1, N2: $3.00 \mathrm{~g}$ pot-1, N3: $4.50 \mathrm{~g} \cdot$ pot-1, N4: $6.0 \mathrm{~g} \cdot$ pot-1, N5: $7.5 \mathrm{~g}$.pot-1. Different letters indicate significant differences $(P<0.05)$ of mean between different nitrogen treatments. 

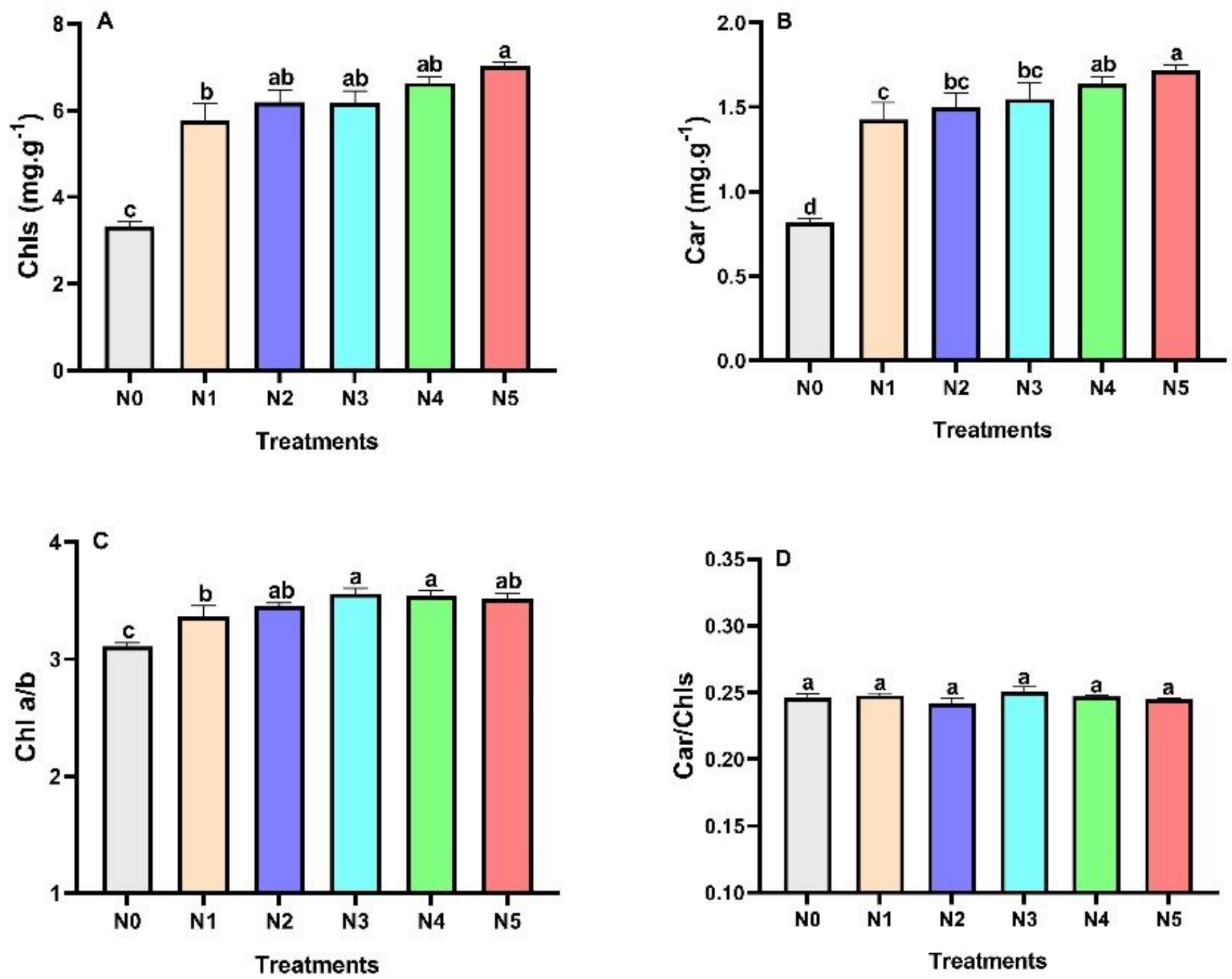

Figure 3

Impact of $\mathrm{N}$ application rate on leaf photosynthetic pigments. (A) Chls - total chlorophylls, (B) Car carotenoids, (C) Chl a/b - chlorophyll a/b ratio, and (D) Car/Chls - carotenoid / total chlorophylls, respectively. N1: 1.50 g.pot-1, N2: 3.00 g.pot-1, N3: 4.50 g.pot-1, N4: 6.0 g.pot-1, N5: 7.5 g.pot-1. Different letters indicate significant differences $(P<0.05)$ of mean between different $N$ treatments. 

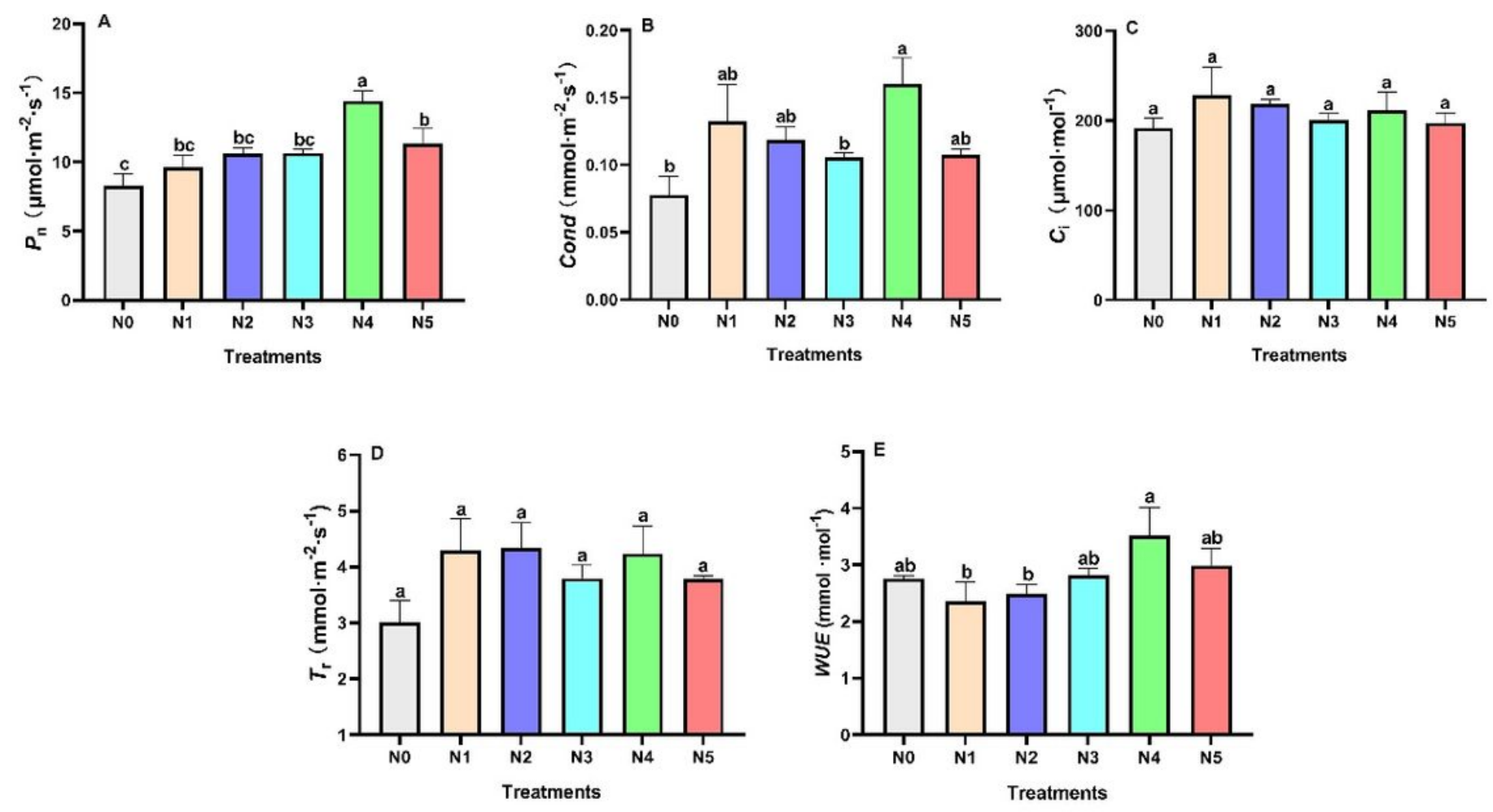

\section{Figure 4}

Leaf gas exchange parameters under different $\mathrm{N}$ application rates. (A) $\mathrm{Pn}-$ net photosynthetic rate, (B) Cond - stomatal conductance, (C) Ci - intercellular CO2 concentration, (D) $\mathrm{Tr}$ - transpiration rate, and (E) WUE - Water use efficiency, respectively. N1: 1.50 g.pot-1, N2: 3.00 g.pot-1, N3: 4.50 g.pot-1, N4: 6.0 g.pot1, N5: $7.5 \mathrm{~g} \cdot$ pot-1. Different letters indicate significant differences $(P<0.05)$ of mean between different $N$ treatments. 

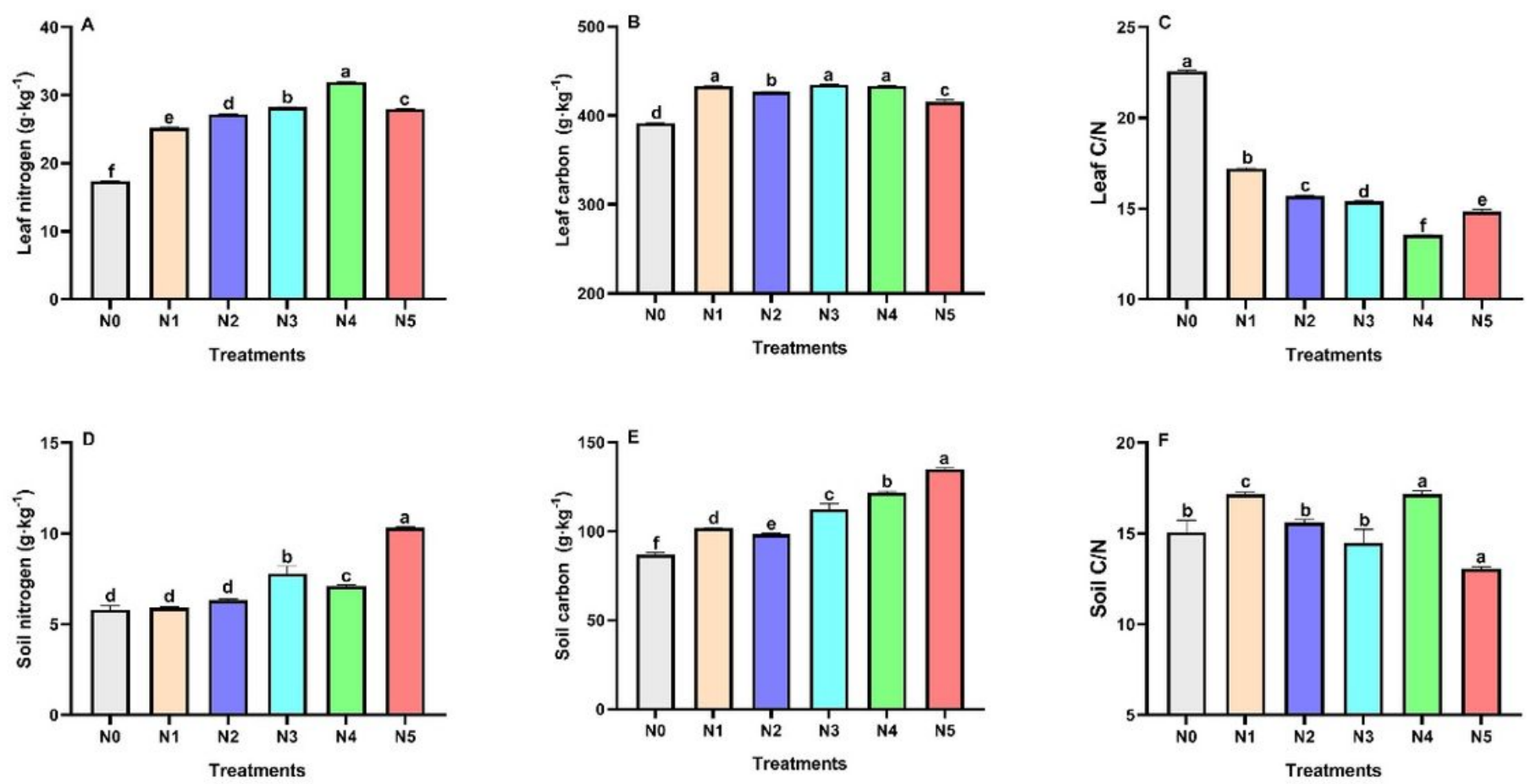

Figure 5

Total nitrogen and carbon indices of leaf and soil. (A) leaf nitrogen, (B) leaf carbon, (C) leaf C/N, (D) soil total nitrogen content, (E) soil total carbon content, and $(\mathrm{F})$ soil $\mathrm{C} / \mathrm{N}-$ Soil $\mathrm{C} / \mathrm{N}$ ratio respectively. N1: 1.50 g·pot-1, N2: $3.00 \mathrm{~g} \cdot$ pot-1, N3: $4.50 \mathrm{~g} \cdot$ pot-1, N4: $6.0 \mathrm{~g} \cdot$ pot-1, N5: $7.5 \mathrm{~g} \cdot$ pot-1. Different letters indicate significant differences $(P<0.05)$ of mean between different $N$ treatments.
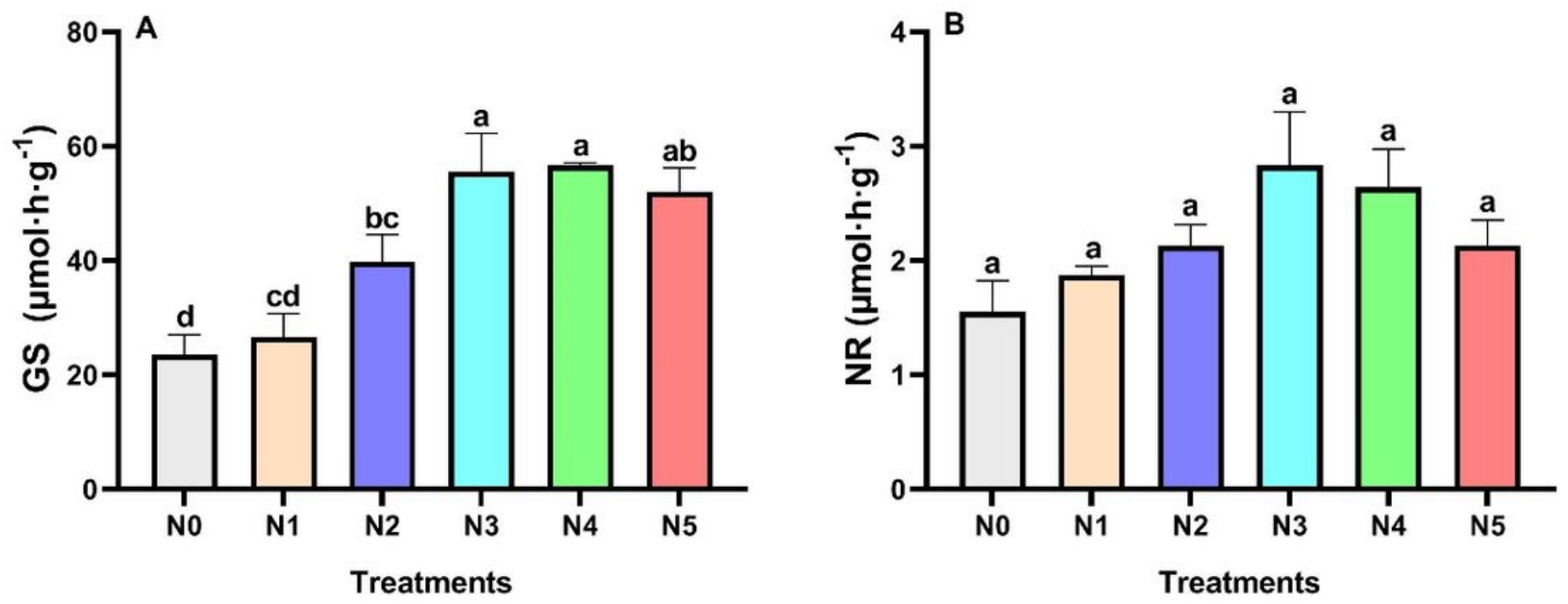

Figure 6 
Impact of various $\mathrm{N}$ application rates on GS and NR activities. (A) GS - glutamine synthetase, and (B) NR - nitrate reductase. N1: 1.50 g.pot-1, N2: 3.00 g.pot-1, N3: 4.50 g.pot-1, N4: 6.0 g.pot-1, N5: 7.5 g.pot-1. Different letters indicate significant differences $(P<0.05)$ of mean between different $N$ treatments.
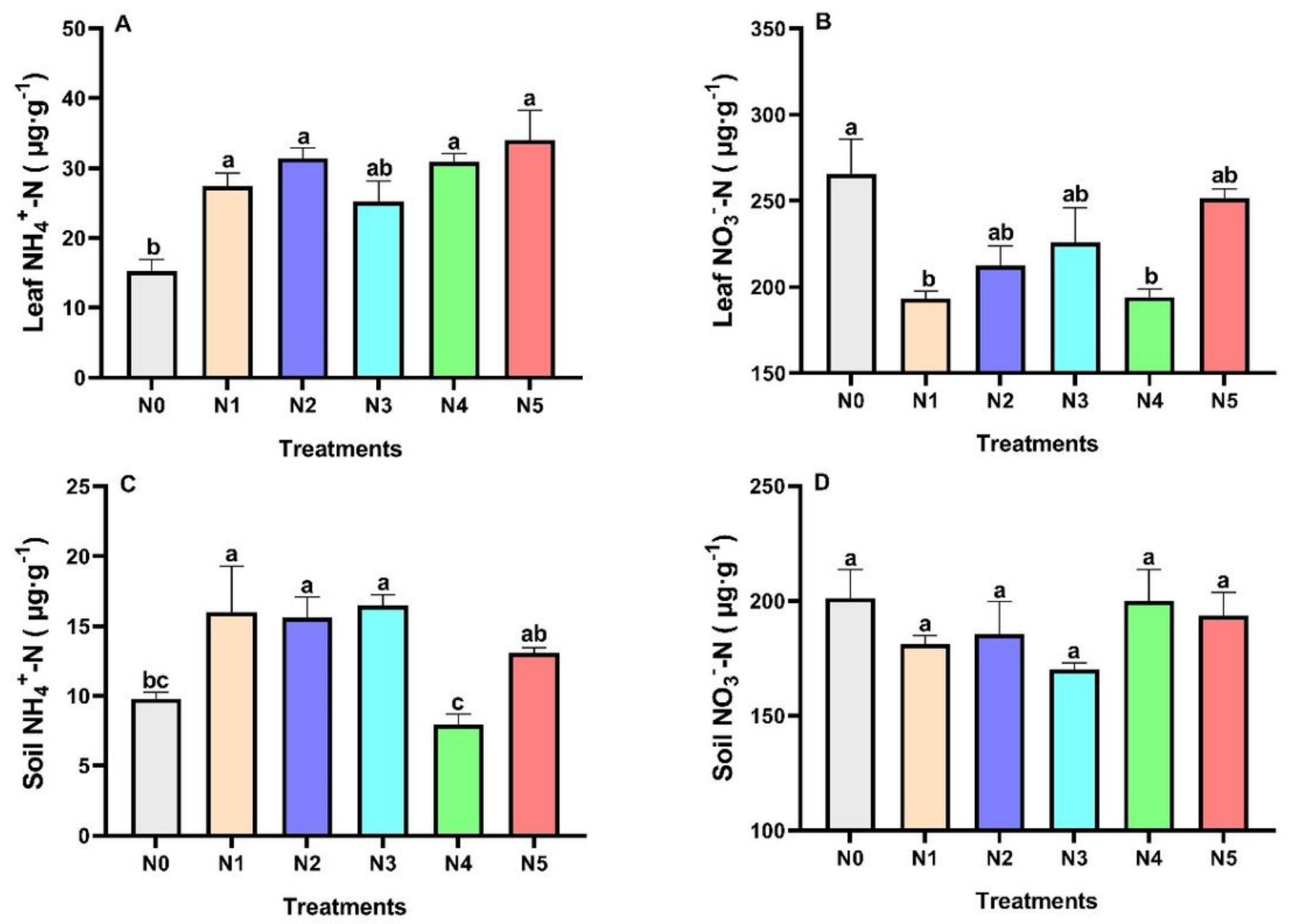

Figure 7

Ammonium nitrogen (NH4+-N) and nitrate nitrogen (NO3-N) of leaf and soil. (A) leaf NH4+-N, (B) leaf NO3-N, (C) soil NH4+-N, and (D) soil NO3-N respectively. N1: 1.50 g.pot-1, N2: 3.00 g.pot-1, N3: 4.50 g.pot-1, N4: 6.0 g.pot-1, N5: 7.5 g.pot-1. Different letters indicate significant differences $(P<0.05)$ of mean between different $\mathrm{N}$ treatments. 


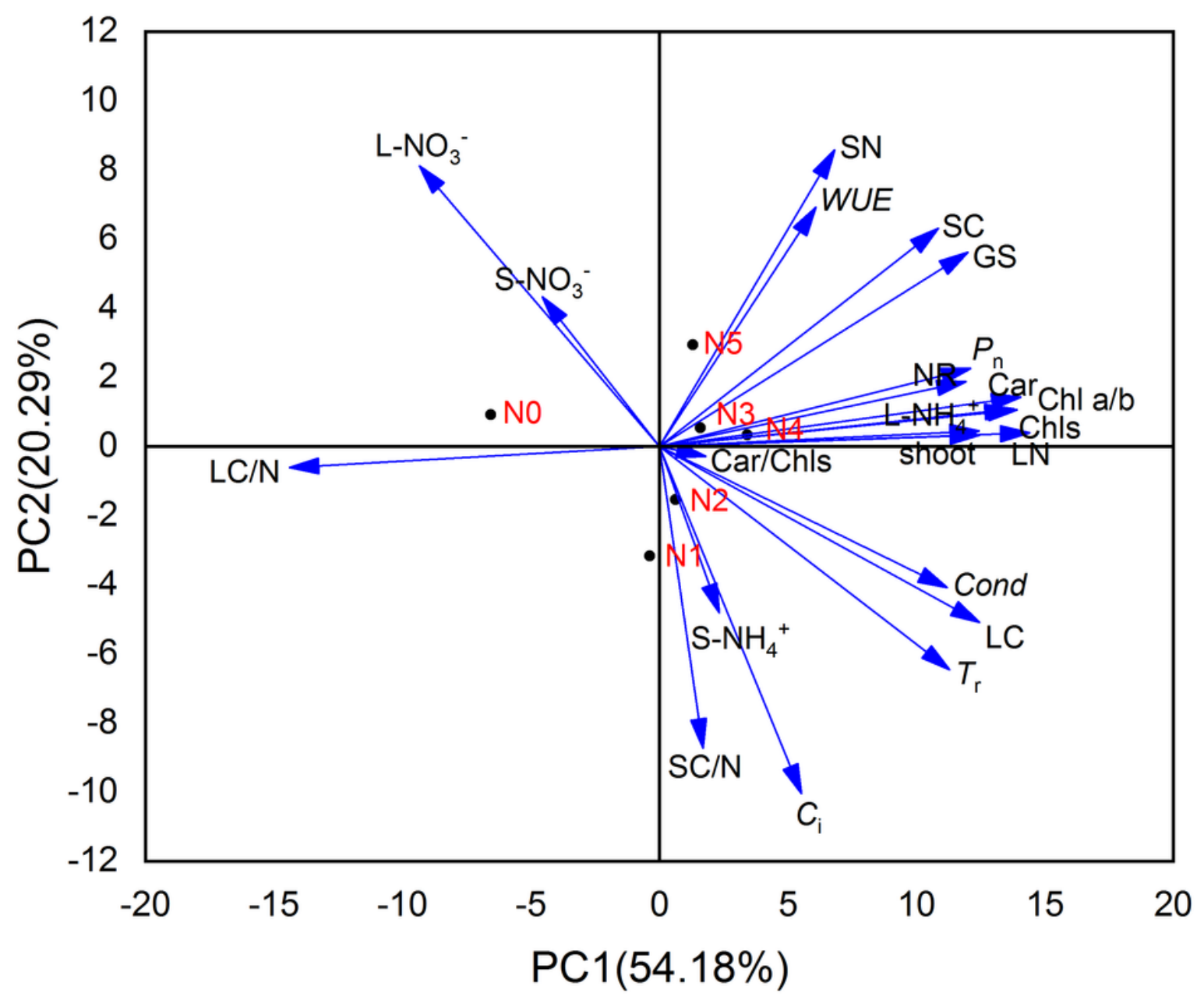

Figure 8

Biplot of principal component analysis of the first two principal components of all tested parameters and $\mathrm{N}$ levels. Shoot - the number of shoots, Chls - total chlorophylls, Car - carotenoids, $\mathrm{Chl} \mathrm{a/b} \mathrm{-}$ chlorophyll a/b, Car/Chls - carotenoid/chlorophyll, $\mathrm{Pn}$ - net photosynthetic rate, Cond - stomatal conductance, $\mathrm{Ci}$ - intercellular $\mathrm{CO} 2$ concentration, $\mathrm{Tr}$ - transpiration rate, WUE - Water use efficiency, GS - glutamine synthetase, NR - nitrate reductase, LN - leaf nitrogen, LC - leaf carbon, LC/N - leaf C/N ratio, $\mathrm{SN}$ - soil nitrogen, $\mathrm{SC}$ - soil carbon, $\mathrm{SC} / \mathrm{N}$ - soil $\mathrm{C} / \mathrm{N}$ ratio, L-NH4+ - leaf ammonium N, L-NO3- leaf nitrate $\mathrm{N}, \mathrm{S}-\mathrm{NH} 4+-$ soil ammonium $\mathrm{N}$, and S-NO3- - soil nitrate $\mathrm{N}$. 